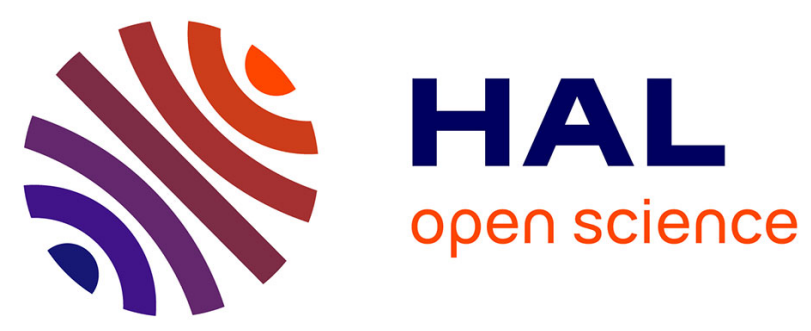

\title{
Epitaxial PZT thin films on YSZ-buffered Si (001) substrates for piezoelectric MEMS or NEMS applications
}

Corentin Jorel, Héloïse Colder, Alice Galdi, Laurence Méchin

\section{- To cite this version:}

Corentin Jorel, Héloïse Colder, Alice Galdi, Laurence Méchin. Epitaxial PZT thin films on YSZbuffered Si (001) substrates for piezoelectric MEMS or NEMS applications. E-MRS 2012 Spring Meeting, Symposium M: More than Moore: Novel materials approaches for functionalized Silicon based Microelectronics, May 2012, Strasbourg, France. pp.012012, 10.1088/1757-899X/41/1/012012 . hal-00813970

\section{HAL Id: hal-00813970 https://hal.science/hal-00813970}

Submitted on 16 Apr 2013

HAL is a multi-disciplinary open access archive for the deposit and dissemination of scientific research documents, whether they are published or not. The documents may come from teaching and research institutions in France or abroad, or from public or private research centers.
L'archive ouverte pluridisciplinaire HAL, est destinée au dépôt et à la diffusion de documents scientifiques de niveau recherche, publiés ou non, émanant des établissements d'enseignement et de recherche français ou étrangers, des laboratoires publics ou privés. 


\title{
Epitaxial PZT thin films on YSZ-buffered Si (001) substrates for piezoelectric MEMS or NEMS applications
}

\author{
Corentin Jorel $^{1}$, Héloïse Colder ${ }^{2}$, Alice Galdi ${ }^{1,3,4}$, Laurence Méchin ${ }^{1}$ \\ ${ }^{1}$ GREYC, ENSICAEN, UCBN, CNRS, UMR 6072, 6 bd du Maréchal Juin, 14050 \\ Caen cedex, France \\ ${ }^{2}$ CRISMAT/CNRT-Matériaux /ENSICAEN, UMR6508, UMS 3318, 6 bd du \\ Maréchal Juin, 14050 Caen cedex, France \\ ${ }^{3}$ CNR SPIN Superconductors Oxides \& Other Innovat M, I-84084 Fisciano, SA, Italy \\ ${ }^{4}$ Univ Salerno, I-84084 Fisciano, SA, Italy \\ E-mail: corentin.jorel@unicaen.fr
}

\begin{abstract}
We report the growth of epitaxial $\mathrm{Pb}\left(\mathrm{Zr}_{0.54} \mathrm{Ti}_{0.46}\right) \mathrm{O}_{3}$ (PZT) thin films on yttriastabilized zirconia buffered silicon substrates by pulsed laser deposition. We demonstrate a full in plane epitaxy of the buffer layer, showing a RMS roughness of less than $0.3 \mathrm{~nm}$ for a 120 $\mathrm{nm}$ thick layer. This buffer layer allows the growth of fully (110) textured oxide conducting $\mathrm{SrRuO}_{3}$ and subsequent functional oxide layers. Here the $\mathrm{Pb}(\mathrm{Zr}, \mathrm{Ti}) \mathrm{O}_{3}$ oxide was chosen to demonstrate its possible integration in piezoelectric microelectromechanical systems on silicon.
\end{abstract}

\section{Introduction}

High quality functional oxides are usually deposited on specific ceramic substrates such as $\mathrm{SrTiO}_{3}$ (STO), $\mathrm{LaAlO}_{3}, \mathrm{MgO}$, etc., which are expensive and not compatible with silicon-based semiconductor technologies or suitable for high frequency applications. Considerable efforts have been made to develop deposition processes of epitaxial functional oxides on Silicon substrate.

Yttria-stabilized zirconia (YSZ) can be used as a buffer layer for the epitaxial growth of oxides on silicon substrates, such as $\mathrm{YBa}_{2} \mathrm{Cu}_{3} \mathrm{O}_{7-\delta}$ (YBCO) [1, 2], $\mathrm{La}_{0.7} \mathrm{Sr}_{0.3} \mathrm{MnO}_{3}$ (LSMO) [3,4], $\mathrm{Pb}(\mathrm{Zr}, \mathrm{Ti}) \mathrm{O}_{3}$ (PZT) [5]. Here we present results obtained by using YSZ buffer layers on silicon for improved piezoelectric PZT thin films by pulsed laser deposition (PLD). To avoid dielectric constant reduction, serious fatigue degradation and blocking contact as commonly observed when using noble metal (Pt) electrodes [6], we considered the $\mathrm{SrRuO}_{3}$ (SRO) oxide as epitaxial conducting electrodes because of its lattice and chemistry match with PZT.

\section{The YSZ buffer and SRO conductive electrode layers}

All layers were deposited in situ by PLD on silicon (001) substrates in a multitarget system without breaking the vacuum using a pulsed $\mathrm{KrF}$ excimer laser $(\lambda=248 \mathrm{~nm})$. YSZ crystallises in a $5.139 \AA$ 
cubic lattice. SRO is a pseudocubic perovskite with a pseudocubic lattice parameter of $3.93 \AA$ (orthorhombic with Pbnm symmetry and lattice parameters $a=5.567 \AA, b=5.5304 \AA$ and $c=7.8446 \AA$ ).

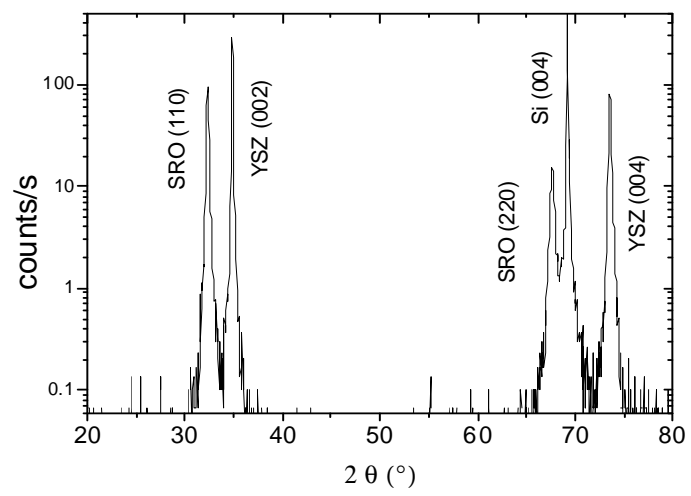

Figure 1. X-ray diffraction patterns in the $\theta-2 \theta$ configuration of SRO / YSZ layers on a silicon (001) substrate.

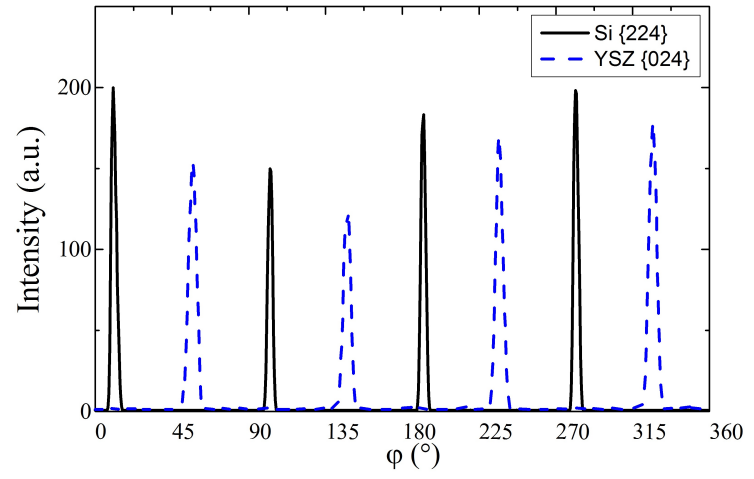

Figure 2. $\varphi$-scan diffraction patterns of the YSZ $\{024\}$ and $\mathrm{Si}\{224\}$ families of plane.

Prior to deposition, the $10 \times 10 \mathrm{~mm}^{2} \mathrm{Si}$ substrates were ultrasonically degreased in acetone and alcohol without any removal of the native oxide. They were mounted on a heater block and heated radiantly. In order to avoid a further growth of the $\mathrm{SiO}_{2}$, the $\mathrm{Si}$ substrates were heated up to the deposition temperature at a residual pressure of $10^{-5} \mathrm{mbar}$. The pressure was increased to $10^{-4} \mathrm{mbar}$ after 30 seconds of deposition of YSZ, which enabled to remove most of the native $\mathrm{SiO}_{2}$ layer by a chemical reaction with $\mathrm{ZrO}_{2}$ or $\mathrm{Zr}$ in vacuum during the first laser shots [7]. The epitaxy could then be established in spite of the primitive $\mathrm{SiO}_{\mathrm{x}}$ amorphous layer. The YSZ deposition temperature was fixed to $700^{\circ} \mathrm{C}$, the laser pulses and energy at $3 \mathrm{~Hz}$ and $220 \mathrm{~mJ}$, respectively. In these optimized deposition conditions, (001) oriented YSZ films were obtained (figure 1). They showed rocking curves full width at half maxima (FWHM) of the YSZ (002) peak of $0.6^{\circ}$.

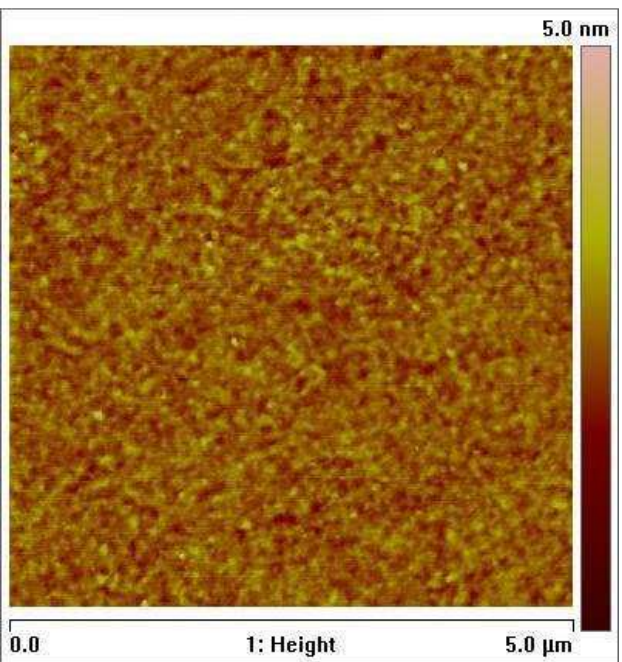

Figure 3. $5 \times 5 \mu \mathrm{m}^{2} \mathrm{AFM}$ images in tapping mode of a $120 \mathrm{~nm}$ thick YSZ layer on $\mathrm{Si}$ (001). RMS roughness: $0.291 \mathrm{~nm}$.

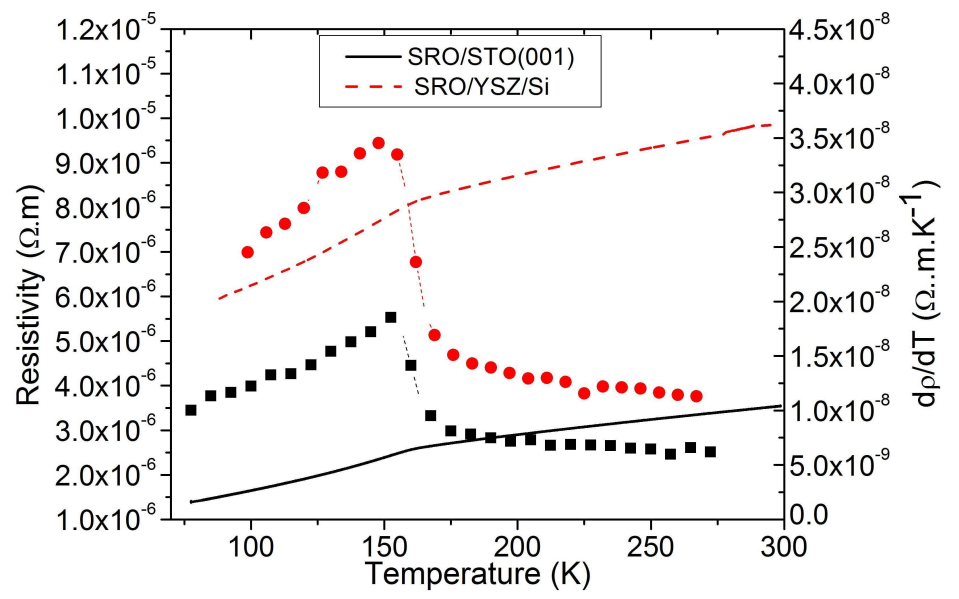

Figure 4. Resistivity versus temperature characteristics (lines) of $30 \mathrm{~nm}$ thick SRO films deposited on YSZ/Si and on STO (001) substrates as a reference. The derivatives are plotted on the right axis (scatter).

The in-plane epitaxial relationships of the YSZ films have been investigated by $\varphi$-scan XRD patterns (figure 2). We have considered the $\{224\}$ families of planes for silicon, and the $\{024\}$ for 
YSZ. The $\varphi$-scan XRD patterns were recorded with the rotation angle $\varphi$ parallel to the [001] direction of each material. As shown in Fig. 2, the shifting by $45^{\circ}$ between the YSZ $\{024\}$ and Si $\{224\}$ families of planes indicates the overlap of all the directions with the same $(h k l)$ indices (YSZ [100]//Si [100] for example). YSZ layers therefore showed a full in-plane epitaxy with a cube on cube alignment with respect to the Si substrate. Finally, YSZ buffer layers showed a low rms roughness of $0.291 \mathrm{~nm}$, calculated with the AFM data presented figure 3 .

The perovskite structure, the compatible lattice parameter, the high conductivity and the chemical compatibility of SRO made it a great candidate for conducting electrodes [8]. SRO was deposited by PLD at $700{ }^{\circ} \mathrm{C}, 2 \mathrm{~Hz}$ and $170 \mathrm{~mJ}$ in an oxygen pressure of 0.2 mbar. Typical layers are $20-80 \mathrm{~nm}$ thick for 1000-3000 laser pulses.

XRD patterns of the SRO/YSZ bilayer on $\mathrm{Si}(001)$ are shown in figure 1 and demonstrate a high degree of crystallinity of the (110) single orientation. Corresponding rocking curves give $0.7^{\circ}$ mean dispersion of the growth axis (FWHM) for the SRO film, which is close to the value of $0.6^{\circ}$ obtained for the YSZ film.

The electrical behavior of the SRO electrode was checked through the resistivity vs. temperature four point measurements shown in figure 4 . As a comparison the characterization of an equivalent film deposited on STO (001) is also shown. Both films show metal-like behavior and resistivity values at ambient temperature are state of the art [8]: 360 and $1000 \mu \Omega . \mathrm{cm}$ for the film grown on STO and Si respectively.

\section{PZT films}

$\mathrm{PZ}_{0.54} \mathrm{~T}_{0.46}$ films were grown on the SRO/YSZ bilayer at $600^{\circ} \mathrm{C}, 5 \mathrm{~Hz}$, with $200 \mathrm{~mJ}$ laser pulses in different $\mathrm{O}_{2}$ atmospheres ranging from 0.05 to $0.5 \mathrm{mbar}$. Due to $\mathrm{Pb}$ loss during the PLD process [9], a $10 \% \mathrm{PbO}$ enriched target was used. The a and c lattice parameters of $\mathrm{PZ}_{0.52} \mathrm{~T}_{0.48}$ are 4.036 and $4.146 \AA$ respectively so that the lattice mismatch with SRO is fairly small $(\sim 2.7 \%)$.

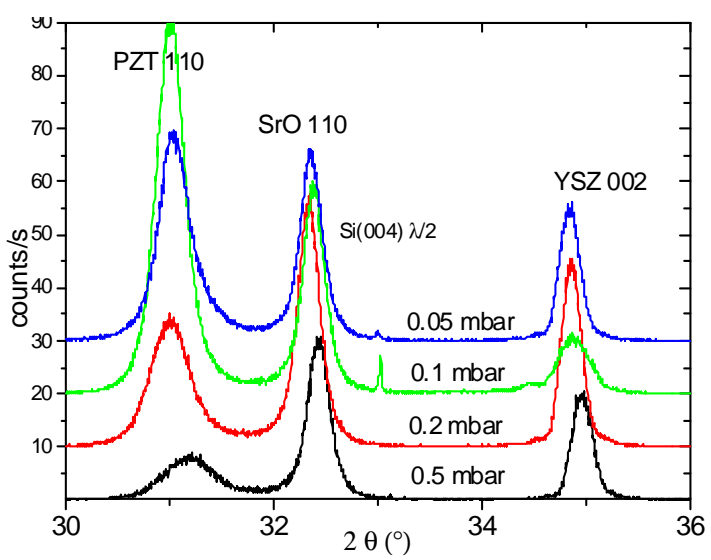

Figure 5. X-ray diffraction patterns in the $\theta-2 \theta$ configuration of $\mathrm{PZT} / \mathrm{SRO} / \mathrm{YSZ}$ layers on $\mathrm{Si}$ for different oxygen pressure.

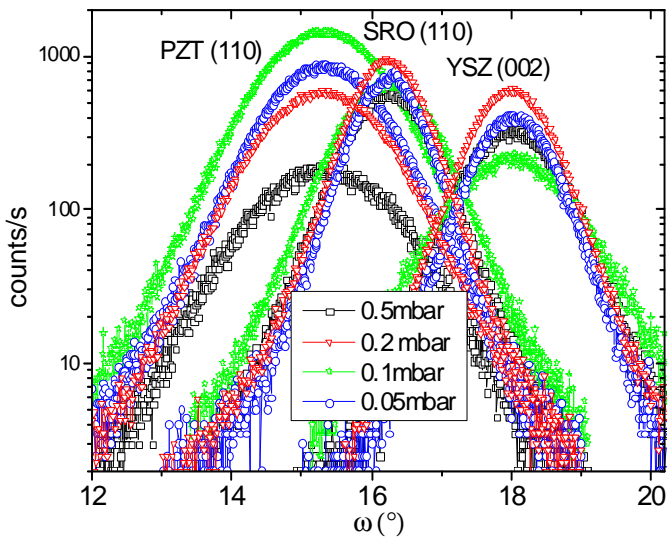

Figure 6. Corresponding rocking curves

XRD diffraction results are presented figures 5 and 6 . All films were fully (110) oriented, growing accordingly with the SRO electrode layer. Best results were obtained at the lower deposition pressure (0.05 mbar) as shown in table 1 below. Moreover, the less crystallized 0.5 mbar film displays parasitic micrograins on AFM scans. The low dispersion of results indicates that PZT are robust to deposition conditions, which is favorable for future applications. 
Table 1. Rocking curve FWHM of the films at different oxygen deposition pressures

\begin{tabular}{|c|c|c|c|}
\hline $\mathrm{P}$ (mbar) & $\mathrm{YSZ}$ & $\mathrm{SRO}$ & $\mathrm{PZT}$ \\
\hline 0.05 & 1.2 & 1 & 1.7 \\
\hline 0.1 & 1.8 & 1.4 & 1.8 \\
\hline 0.2 & 1.2 & 1 & 1.8 \\
\hline 0.5 & 1.4 & 1.2 & 2.1 \\
\hline
\end{tabular}

\section{Conclusion \& perspectives}

Epitaxial SRO/YSZ bilayers were grown by PLD on silicon (001) substrates. Both films type showed excellent crystalline properties and SRO exhibited a fully metal-like behavior.

This bilayer constitutes a very versatile building block for further functional oxide deposition. We showed that fully oriented (110) PZT could be grown on top of it. Further work has now to be conducted for the use of these layers in microelectromechanical and nanoelectromechanical devices [10].

\section{References}

[1] L. Méchin, J.C. Villégier, G. Rolland, F. Laugier, Physica C 269 124-30 (1996)

[2] L. Méchin, G. Huot and D. Bloyet, Appl. Phys. Lett. 853154 (2004)

[3] L. Méchin, P. Perna, C. Barone, J.-M. Routoure, Ch. Simon, Mater. Sci. And Engine. B 144 737 (2007)

[4] P. Perna, L. Méchin, M.P. Chauvat, P. Ruterana, Ch. Simon, and U. Scotti di Uccio, J. Phys. : Condens. Mat. 21306005 (2009)

[5] M. Dekkers, M.D. Nguyen, R. Steenwelle, P.M. te Riele, D.H.A Blank, and G. Rijnders, Appl. Phys. Lett. 95012902 (2009)

[6] R. Ramesh, W.K. Chan, B.Wilkens, H. Gilchrist, T. Sands, J.M. Tarascon, V.G. Keramidas, D.K. Fork, J. Lee, and A. Safari, Appl. Phys. Lett. 611537 (1991)

K. Yokota, H. Morigou and F. Miyashita, Nucl. Ins. \& Method. In Phys. Res. B 257468 (2007).

L. Qiao and X. Bi, J. of All. \& Comp. 477560 (2009).

B. Chen, H. Yang, J. Miao, L. Zhao, L. X. Cao, B. Xu, X. G. Qiu, and B. R. Zhao, J. Appl. Phys. 97024106 (2005).

[7] S. J. Wang, C. K. Ong, L. P. You, and S. Y. Xu, Semicond. Sci. Technol. 15836 (2000).

[8] G. Koster, L. Klein, W. Siemons, G. Rijnders, J.S. Dodge, C.-B. Eom, D.H.A. Blank, M.R. Beasley, Rev. Mod. Phys. 84 253-98 (2012)

[9] R. Thomas, S. Mochizuki, T. Mihara, T. Ishida, Mater. Sci. And Engine. B 9536 (2002)

I.M. Reaney, K. Brooks, R. Klissurska, C. Pawlaczyk, N. Setter, J. Am. Ceram. Soc. 771209 (1994)

[10] C. Ayela, T. Alava, D. Lagrange, D. Remiens, C. Soyer, T. Ondarcuhu, A.Greve, L.Nicu, IEEE Sensors J. 8 (3) 210 (2008)

T Alava, F Mathieu, L Mazenq, C Soyer, D Remiens and L Nicu, J. Micromech. Microeng. 20 075014 (2010) 